\title{
CROSS-DRESSING TO BACKBEATS: \\ The Status of the Electroclash Producer and the Politics of Electronic Music
}

\author{
$\multimap$ Feature Article $\longrightarrow$ \\ DaVid Madden \\ CONCORDIA UNIVERSITY (CANADA)
}

\begin{abstract}
Addressing the international emergence of electroclash at the turn of the millenium, this article investigates the distinct character of the genre and its related production practices, both in and out of the studio. Electroclash combines the extended pulsing sections of techno, house and other dance musics with the trashier energy of rock and new wave. The genre signals an attempt to reinvigorate dance music with a sense of sexuality, personality and irony. Electroclash also emphasizes, rather than hides, the European, trashy elements of electronic dance music. The coming together of rock and electro is examined vis-à-vis the ongoing changing sociality of music production/ distribution and the changing role of the producer. Numerous women, whether as solo producers, or in the context of collaborative groups, significantly contributed to shaping the aesthetics and production practices of electroclash, an anomaly in the history of popular music and electronic music, where the role of the producer has typically been associated with men. These changes are discussed in relation to the way electroclash producers Peaches, Le Tigre, Chicks on Speed, and Miss Kittin and the Hacker often used a hybrid approach to production that involves the integration of new(er) technologies, such as laptops containing various audio production softwares with older, inexpensive keyboards, microphones, samplers and drum machines to achieve the ironic backbeat laden hybrid electro-rock sound.
\end{abstract}

KEYWORDS: electroclash; music producers; studio production; gender; electro; electronic dance music

Dancecult: Journal of Electronic Dance Music Culture 4(2): 27-47 ISSN 1947-5403 @2011 Dancecult http://dj.dancecult.net DOI: $10.12801 / 1947-5403.2012 .04 .02 .02$

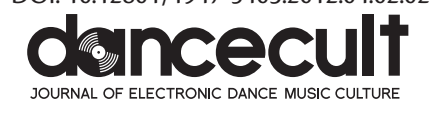


David Madden is a $\mathrm{PhD}$ Candidate (A.B.D.) in Communications at Concordia University (Montreal, QC). Madden's research focuses on sound studies, electronic/popular music, gender and research creation. A lifelong multi-instrumentalist musician, his artistic practice involves electronic music production, sound design, and making videos. Along with independently producing and releasing music and videos, Madden's sound works have been commissioned for contemporary dance works, research projects, videos and performances. <http://www.miraclebabysound.org/>

\section{INTRODUCTION}

IN THE FALL of 2009 I attended an electronic dance music ${ }^{1}$ party night held in Montreal, Québec at la Société des Arts Technologiques (SAT), featuring electroclash (discussed below) pioneers Alter Ego and two Montreal-based DJs, Jordan Dare and Duvall, who also work within the frames of electro and techno. Alter Ego is a German electronic dance music production/performance duo comprised of Roman Flügel and Jörn Elling Wuttke. Touted by Montreal Mirror's former dance music critic Jack Oatmon as "among the most talented, longstanding and influential techno producers in the world" (2009), Flügel and Wuttke present themselves as "Alter Ego Live" while touring. After more than ten years of producing remixes, singles and albums, Flügel and Wuttke released the song "Rocker" in 2004, reaching \#32 on the United Kingdom (U.K.) Singles Chart and becoming one of the most popular instrumental tracks of electroclash (Roberts 2006: 21). In the same year, they won three major awards in Groove Magazine's Readers' Poll, including "Best Live Act", "Best Album" (Transphormer) and "Best Track", for the aforementioned "Rocker" (Resident Advisor 2005).

Alter Ego's performance in Montreal, coming a full five years after the release of "Rocker", led me to consider electroclash and how it emerged as a dominant form of electronic dance music in the early 2000s. Electroclash is comprised of a "consortium of subgenres", to borrow from Charles Kronengold (2008: 45), that combine the extended pulsing sections of techno, house and other dance musics with the reckless energy of rock and new wave. The genre signals an attempt to reinvigorate dance music with a sense of sexuality, personality and irony. Electroclash also emphasizes, rather than hides, the European, trashy elements of electronic dance music. In this sense, the term "electrotrash" might work just as well as "electroclash" to represent the genre. I would like to use the specificity of this cultural moment to address the emergence of electroclash by asking: what is distinct about the genre and its related practices, both in and out of the studio? Why do rock and electro come together at this point and in this way? And, what does electroclash portend in terms of our understandings of the politics of electronic music? Using Stuart Hall's oft-cited conception of articulation, none of these connections are inherently linked; rather, they exist "historically in a particular formation", fashioned by social and cultural practice (1986: 54-55). 
This article argues that the coming together of rock and electronic dance music can be explained vis-à-vis the ongoing changing sociality of music production/distribution and the changing role of the producer. ${ }^{2}$ Instead of the monopolistic practices one sees in other media industries, or even in certain strands of popular music production earlier in the 20 th century where a single firm controlled every aspect of production, including distribution and sales, with electroclash, many of the hierarchical and specialized duties of multitrack studio recording collapse around multi-tasking (digital) studio producers who can potentially control production, distribution, performance duties and the circulation of their aesthetics. It is worth emphasizing that these production practices are not exclusive to electroclash, let alone the professional music industry, as many noncommercial and amateur artists work in similar ways. Numerous women, whether as solo producers or in the context of collaborative groups, have contributed significantly to shaping the aesthetics and production practices of electroclash, an anomaly in the history of popular music and electronic music, where the role of the producer has typically been associated with men. These changes will be discussed in relation to the way electroclash producers Peaches, Le Tigre, Chicks on Speed, and Miss Kittin and the Hacker often used a hybrid approach to production that involves the integration of new(er) technologies, such as laptops containing various audio production softwares, with older, inexpensive keyboards, microphones, samplers and drum machines in order to achieve the ironic backbeat-laden hybrid electro-rock sound.

\section{Electro/Clash}

GIVEN THAT electroclash is still understudied, particularly in relation to its history, producers and production practices, I begin by addressing certain conceptual distinctions between electro and some of its variations, and the broader international emergence of electroclash. Electro currently operates as one of the primary defining categories of electronic dance music and includes the genres of house and techno, among others. Electro primarily functions as a prefix in tandem with various musical descriptors, practices, and/ or vibes (as in, electroclash), and at times the genre is shortened to "electro". Electro initially represented a down-tempo (that is, slower) and funkier manifestation of the electronic funk/rap music that emerged in the early 1980s throughout certain urban centers in the Western world, most notably New York City, where radio stations such as Kiss FM and WBLS mixed the genre into its electronic dance rotation (Rietveld 2012). Electro from this period, interchangeably referred to as electro-funk-as in, electronic funk music-and electro-boogie, is associated with the mechanical sounds produced by Roland's TR- $808^{3}$ drum machine, as well as synthesizers and funky, repetitive bass lines, a holdover of disco and 1970s funk. Electro also draws heavily from early hip hop, often incorporating similar vocal stylizations; additionally, vocal tracks of the electro genre frequently feature the use of vocoders ${ }^{4}$ and/or various other effects. Susana Loza describes the process of adding vocoders as "the 'Planet Rock'/electro effect" (emphasis original), referencing Afrika Bambaata and the Soul Sonic Force's seminal "Planet Rock" (1982), where "normal vocals are forcefed through a vocoder and cartoonishly mangled into a 1950s-style robotized version 
of the original" (2001: 350). Bambaata's "Planet Rock", which incorporates elements of Kraftwerk's "Trans Europe Express" (1977) and is heavily influenced by the work of Yellow Magic Orchestra (YMO), G.L.O.B.E. and Wiz Kid's song "Play that Beat Mr. DJ" (1983), and Cybotron's "Clear" (1983) are all foundational cuts of this early strand of electro.

Even though the electro of the 1980s is very commonly referred to as either electro, electro-funk or electro-boogie, there is generally a tremendous amount of disagreement amongst electronic dance music producers, consumers, listeners and scholars when it comes to fixing certain musical styles within genre boundaries. Mark J. Butler refers to the work of the group Cybotron as "proto-techno", as one of its members, Juan Atkins, is considered to be one of the first techno producers. Atkins, along with Derrick May and Kevin Saunderson, are known as the Belleville Three, alluding to Detroit, Michigan's southwestern suburb (Butler 2006: 42-5). Butler is careful to note, however, that genre "tensions call into question the unity that characterizes most historical narratives of" electronic dance music (2006: 45-6). The apparent lack of genre cohesion and naming within electronic dance music also extends into broader historical narratives and conceptions of electronic music. As Andra McCartney posits, one of the many challenges of defining electronic music is that the term "electronic music" is often used interchangeably with electroacoustic music, even by noted scholars and in important library collections. Further, related terms like musique concrète, computer music and tape music are also frequently employed in overlapping ways (McCartney 2000b: 4). ${ }^{5}$ In other words, electronic music in its many forms and contexts is a rather fluid concept that can be used to describe anything from computer music to production techniques that use recorded sounds and microphones. ${ }^{6}$

Although electroclash is one of the key innovations of electronic dance music of the last decade or so, it has not restructured dance music in the same way as previous developments have. Unlike the emergence of house music in the mid-1980s, electroclash does not represent a total reorientation of electronic dance music culture. Will Straw writes that house music's greater "importance comes from its recentring of the historical movement of dance-music culture as a whole" (1991: 383). Straw continues:

As was the case prior to the rise of house, dance-music within the Western world has continued to be marked by opposed tendencies towards unity/coherence and diversity/differentiation, but the logics through which these processes unfold have become much more integrated. On the one hand, house music has drawn most dance-musical forms into various sorts of accommodation to it.... At the same time, however, the durability and expansiveness of appeal of house music are such that these variations have come to be positioned laterally within a division of tastes running across dance-music culture (Straw 1991: 383).

So, in thinking about electroclash as one of these lateral divisions, the genre has reoriented electronic dance music in many important ways, particularly in relation to production practices, aesthetics and the prominent role of women producers and performers. It is for these reasons that the focus of this text largely revolves around these intersections. 
The emergence of electroclash stems from changes to electronic dance music culture in the late 1990s and early 2000s, changes that can be initially traced to the circulation of emotions and vibes emanating from parties and club nights around this time. "Vibes" is a term that is generally employed by electronic dance music consumers and producers to represent the overall feel of electronic dance music party nights and events. In speaking of Kingston, Jamaica's dancehall scene, Julian Henriques writes that the term vibes is "commonly used to describe the mood, atmosphere or ambience of a session, with the adjective 'vibesy"' (2010: 63). While I would disagree with Henriques' notion that "such affective qualities are considered irreducible, requiring no further explanation, as with feelings themselves" (2010: 63), mainly because not all party night attendees feel the same way, and as Sara Ahmed points out, "even when we feel we have the same feeling, we don't necessarily have the same relationship to the feeling" (2004: 10), Henriques notes that these vibes, which I would suggest are bound up with emotions, can circulate and propagate as repeating frequencies far beyond the confines of a dance floor or dancehall (2010: 70-5). Going further, it might be tempting to think of vibes as having a certain degree of agency, sociality and intentionality as they circulate and come into contact with more and more bodies. ${ }^{7}$

Electroclash emerged in the early 2000s in various electronic dance music centers, such as New York, Berlin, Chicago, Detroit and Montreal, as the emotive response of many DJs, producers, club promoters, listeners and dancers who observed or perhaps more accurately, felt, that certain styles of electronic dance music (e.g. minimal techno) were too serious and austere. The "back-to-basics" sound of electroclash, which, in part, was a reaction against the perceived excesses of the electronic dance music of the late 1990s, was embraced by the fashion-conscious worlds of New York and London (and electroclash artists), along with 1980s synth-pop, from Gary Numan and Soft Cell to The Human League. ${ }^{8}$ In a personal interview with Montreal-based party host, dancer and electroclash promoter Mikey Muscles, he suggests that by the early 2000s club nights and events were "just not enough fun; they took themselves too seriously". 9 While mentioning electroclash's connection with the past, label manager and A\&R for Turbo Recordings, Thomas Sontag, elaborates on some of Muscles' sentiments:

[Electroclash] ... was a revisiting of the past. Like it was pastiche to begin with. .. . I think it came out of the rise of dance music culture, the continued rise of dance music culture and a movement away from a lot of the kind of facelessness and lack of personality of like, post-rave big club DJing and stuff like that and a lot of the dull repetition of clubs ... and in Montreal and globally, quite a lot of pretty boring, pretty standard house music and darker techno.... Electroclash picked up a lot of really simple elements that never really lost their appeal to people. ${ }^{10}$

The assortment of sounds and music associated with this movement away from the experienced boredom of techno party nights and the facelessness of post-rave big club DJing, as Sontag calls it, initially developed without a conceptual home, as the term electroclash only came into use a full two years after many producers and groups were attempting to articulate music along these lines. 
Larry Tee is a longtime club promoter, music producer and DJ based in New York City and claims a certain paternity in coining the term electroclash, even having the term trademarked in 2001. As Brent Luvaas writes, Tee used electroclash "to describe a diverse set of young performers doing 'different but related' things with electronic music" (2006: 171). In 2001 and 2002, Tee founded and ran the Electroclash Festival featuring Felix Da Housecat, Peaches, 2 Many DJs/Soulwax, along with many other artists. What is perhaps most interesting about Tee's Electroclash Festival and early definitions of the genre is that his definition included everything from the dance-y/glam-ish rock sounds of the Scissor Sisters to the sleazed-up house tendencies of Felix da Housecat. And, while the return to some idea of the distinct track/song was one of electroclash's defining features, so too was the prominent way that so many women and gender-bending performers significantly contributed to the genre's production and distribution practices. The aforementioned Alter Ego along with Peaches-whose album The Teaches of Peaches (2000) is perhaps the most widely known full-length album of electroclash music-Le Tigre, Ellen Allien, Chicks on Speed, Tiga, Miss Kitten and the Hacker, and many others were at the forefront of the emergence of the genre.

At the centre of electroclash's new celebrated sexuality and gender play within electronic dance music is the Berlin-based Canadian artist Peaches (née Merril Nisker), who has released four full-length albums since 2000: The Teaches of Peaches (2000), Fatherfucker (2003), Impeach My Bush (2006) and I Feel Cream (2009). Marnina Gonick describes Peaches as "a gender provocateur" (2009: 139) who, through her music, performances and her use of parody, deploys a "disruptive pedagogy" that "destabilizes fixed notions of sexuality, rendering the body and sex as comical” (2009: 140-2). Going further, Stéphane Girard writes:

[The] Electroclash movement, contrary to the faceless, sex-less and pre-Oedipal approaches to techno in the 1990s, was never afraid of domineering, strongly gendered performers who toyed with the signifiers of gender representation and various popular music-bound generic conventions in overtly explicit ways. Examples include Peaches, who has been photographed wearing underwear and revealing a stuff black penis and out-of-control pubic hair (2011: 119).

Key tracks from Peaches' electroclash-oriented material include "Fuck the Pain Away" from The Teaches of Peaches, and "Shake Yer Dix" from the album Fatherfucker. Beyond elements of sexuality and trashiness, the former song is driven by synthesizer bass lines and plays with the backbeat conventions that provide the rhythmic moorings of electroclash. Nancy Bottner, who characterizes Peaches as a "Sonic Cyborg" by drawing attention to her imagery and lyrics, describes the artist's music as "recorded very roughly, noisy, focused on voice and beat", and "merging (post)punk attitude with 80s electronic music" (2005: 99). Perhaps the most pronounced aesthetic feature of "Fuck the Pain Away", along with many other early electroclash songs, is the heavy reliance on synthesized, participatory hand-claps and the incorporation of vocals, almost following, or parodying, the classic folk and (cock) rock-song structure of a verse followed by a chorus. 
Between 2000 and 2002, Peaches' "Fuck the Pain Away" and Miss Kittin and the Hacker's "Frank Sinatra", from First Album (2001), became two of electroclash's prototypical tracks. The vocals of "Fuck the Pain Away" and "Frank Sinatra" are marked by an explicit and detached irony exhibited in both the tone of the vocal deliveries and content of the lyrics. This type of ironic vocal posturing is perhaps what connects electroclash most stridently with new wave and other forms of popular music, which, as Kronengold tells us, often "parodize in the lyrics" while being "dead serious in the music" (2008: 58). Irony also serves as a powerful production method for electroclash artists to explicitly play with gender norms and sexual practices through their lyrics. As David Foster Wallace writes, "for irony-exploiting gaps between what's said and what's meant, between how things try to appear and how they really are-is the time-honored way artists seek to illuminate and explode hypocrisy" (1997: 65), adding, "gifted ironists work best in sound bites" (1997: 67). In the first verse of "Fuck the Pain Away", Peaches opens with: "Sucking on my titties like you wanted me/Calling me, all the time like Blondie/Check out my chrissy behind/It's fine all of the time/Like sex on the beaches/What else is in the teaches of peaches? Huh? What?". During an interview with Caroline Sullivan from The Guardian in support of her second studio album Fatherfucker (2003), where Sullivan refers to Peaches as "an equalopportunities vulgarian", Peaches remarked about the album's title: "Motherfucker's so over. You call everybody a motherfucker-you call your mother a motherfucker. It's a pretty extreme and intense word. Instead of shying away from that, I thought I'd bring the fact that we're using the word motherfucker in a really mainstream way to the fore" (Sullivan 2006).

Other electroclash artists like Chicks on Speed and Le Tigre use irony and gender parody to deliver overtly feminist messages and/or align their music with feminist commitments, whether they refer to themselves as feminists or not. As Judith Butler writes, "gender parody reveals that the original identity after which gender fashions itself is an imitation without an origin. To be more precise, it is a production which, in effect-that is, in its effect-postures as an imitation" (1990: 188). Chicks on Speed's most well known track from their electroclash-oriented material is the playfully entitled "We Don't Play Guitars", the first single from their album 99 Cents (2003), which was released on their own record label, Chicks on Speed Records. The track features the lyrics: "We always thought that we were not a rock 'n' roll band, but it sure feels like rock n' roll over here tonight/We don't play guitars/We don't play guitars/We don't play guitars/We're standing on stage with our microphones, but we don't play guitars". Peaches makes an appearance halfway into the song and shouts out, "[W] ]ell you may not play guitar but I play guitar/And I love it", before performing a highly distorted shredding guitar solo, which the artist mimes or "air guitar"-s in the track's video while simultaneously floating above and facing the members of Chicks on Speed, strategically holding an electric Gibson Flying V guitar between her legs.

Le Tigre, a feminist electronic music and performance art group (Rodgers 2010: 245), released Feminist Sweepstakes in 2001 on the San Francisco-based lesbian-feminist independent record label and video art distributor Mr. Lady, which folded in 2004. As Tara Rodgers writes, Le Tigre's "lyrics engage feminist and queer histories and politics" (2010: 
245). In "Hot Topic", the lead-off single from their self-titled debut album, Le Tigre (1999), which Rodgers notes "proclaims a litany of artists, activists and writers who have inspired them" (2010: 245), the group-whose members include Kathleen Hanna (formerly of riot grrrl group Bikini Kill), Johanna Fateman, and JD Samson — calls out to numerous (women) artists, letting them know they are still listening: "Carol Rama and Eleanor Antin/Yoko Ono and Carolee Schneeman /You're getting old, that's what they'll say, but/Don't give a damn I'm listening anyway". Women often find themselves pulled in two directions at the same time when working in highly masculinized technological fields, such as electronic music production: they are torn between downplaying aspects associated with femininity and pursuing a stereotypically masculine stance of control, or denying a connection with masculinity and taking a stereotypically feminine stance (McCartney 2000a: 317-8). One way to overcome this conflict, as McCartney writes, is to forgo swaying one way or another and pursue a strategy of irony, which "acknowledges contradictions without attempting to resolve them" (2000a: 318).

In addition to the ironic stances taken by many of its producers and performers, electroclash signals a rhythmic shift within electronic dance music through the incorporation and circulation of the backbeat. The genre fits within a continuum of practices that are directly connected to the rise of house music in Chicago in the mid-1980s (Straw 1991) and disco in the early 1970s (Lawrence 2003), both of which share the "four-on the-floor" with variations (e.g. tempo, timbre, etc.) as their structuring groove. Again, electroclash is marked by a certain hybridity, combining the extended pulsing sections of techno and other dance musics with the song structural elements and reckless energy of various rock musics. As Oatmon puts it, electroclash "mimics rock composition and sound quality without using any actual rock instruments" (2009), although numerous bands (e.g. Le Tigre, Chicks on Speed, LCD Soundsystem) contributed to the early stages of electroclash using traditional rock instruments such as electric guitars and drum sets. As Luvaas notes, "indie electropop bands like Ladytron, Soviet, and the Faint were equally if not more responsible for popularizing" the electroclash genre (2006: 171). Many electroclash DJs and producers typically import a standard rock backbeat with much more aggressive and synthesized drum sounds and textures/timbres within the established conventions of electronic dance music tempi or BPM (beats per minute). ${ }^{11}$ For instance, Tiga and Zyntherius' "Sunglasses at Night", which sold over 200000 copies in Europe (primarily in Germany and the UK), clocks in at 130 BPM (Girard 2011: 110,116). Until the mid-2000s, it was not uncommon to hear hard rock, post-punk and new wave hits mixed into live electroclash DJ sets-the Cult's "She Sells Sanctuary" (1985), Joy Division's "Love Will Tear Us Apart" (1980) and New Orders' "Blue Monday" (1983) were often featured at clubs and parties around this time.

The integration of the backbeat follows a trajectory of changes in electronic dance music revolving around slight rhythmic adjustments, usually very specifically ascribed to a few individuals or particular samples. ${ }^{12}$ A recent example of this rhythm phenomenon, and one which echoes the developments of reggae and dub, is found in drum ' $n$ ' bass in the mid- 
1990s, with the "Amen Break" serving as the core element of this genre and its variations. The Amen Break, usually shortened to just "Amen", is a sample from a short solo drum break played by Gregory C. Coleman on the Winston's "Amen, Brother" (1969), the B-side to the single "Color Him Father". The Amen break was initially used in early hip hop recordings, in part because a slowed down version of it was featured on Ultimate Breaks and Beats (1986), a compilation album of sampled drum grooves put together by Breakbeat Lenny (né Lenny Roberts) for its viral potential. As Steve Goodman puts it: "[What] the riddim album captures is the startling efficiency of breeding whole sonic microcultures out of one core loop" (2008: 161). In the context of drum 'n' bass, the Amen is sampled, manipulated, or "cut up" and sped up, regularly at tempi exceeding 180 BPM. ${ }^{13}$

Like the Amen, the backbeat has its own origin story in popular music, with its roots in gospel music, early rock and roll and the recordings of Little Richard and Chuck Berry. John Mowitt writes, in Percussion: Drumming, Beating, Striking, about how the backbeat emerged out of efforts by the "extraordinarily influential and woefully underrated session drummer Earl Palmer" to "answer to the accompaniment demands placed on him by a particular way of performing what were basically blues tunes" (2002: 26). As Palmer remarks, "the only reason I started playing what they come to call the rock-and-roll beat came from trying to match Richard's right hand. Ding-ding-ding-ding! Most everything I had done before was a shuffle or slow triplets" (in Mowitt 2002: 26). After Palmer's early rhythm experiments with the groove, the backbeat would develop into the standardized rhythmic pattern of numerous popular musics, including rock music. As Mowitt emphasizes, "virtually every popular song that actually has a drum part now employs some variation of the backbeat" (2002: 26).

The backbeat pattern is generally deployed in the context of a standard drum kit by using the bass drum (or "kick" drum) to mark the first and third beats of a measure and using the snare drum to hit beats two and four. In other words, the snare answers back to the call of the bass drum, which Mowitt ascribes to "the African tradition of 'call-and-response' drumming patterns" (2002: 26). The hi-hat, or ride cymbal, simultaneously provides the glue, the momentum and the straight eighth-note feeling of the groove by playing either straight quarter or eighth notes, as opposed to the shuffle or slow triplets feel mentioned above by Palmer (Mowitt 2002: 26). In the context of electroclash, the backbeat is very regularly incorporated in a much more mechanized fashion; most recordings employ drum machines and sequencing technology to program the beats, resulting in perfect and unwavering metronymic time, usually between 120-35 BPM. This groove is played out in the aforementioned "Frank Sinatra", although with a common variation-the hi-hats emphasize the offbeat of each measure, importing one of disco's standard hi-hat patterns and giving the track a much lighter feel. 


\section{PRODUCERS}

THE VARIOUS backbeats of electroclash emerged out of a production context of change, both in terms of the sociality of studio production and the role of the producer. As Emma Mayhew posits vis-à-vis popular music, "the producer's role has remained a male domain", and at the "top end of the recording industry women are significant by their absence as record producers" (2004: 149). Similarly, Bottner writes that, in accordance with other areas of popular music production, "electro is dominated by male producers/users and the absence of women is explained through recourse to the all too familiar dichotomies: competence and interest in soft/hardware technology or computer science are mainly ascribed to men, whereas women are understood as engaging with her body" (2005: 102). While I agree with Bottner's sentiment that electronic music production is dominated by men within the broader boundaries and context of electro, electroclash is significantly defined and inhabited by women music producers, performers, label owners and scene actors. In addition to Peaches, Chicks on Speed and Le Tigre, as discussed above, other artists like Ellen Allien (née Ellen Fraatz) ${ }^{14}$ factor heavily in shaping electroclash on many different levels by taking on both entrepreneurial and artistic roles. In fact, drawing on the careers of the above named artists along with recent scholarship on the subject of DIY DJs in Vienna (Reitsamer 2011), it can be persuasively argued that a certain entrepreneurial experience seems to be an essential skill for artists working within the realm of current commercially produced electronic dance music.

In the history of popular music, the term producer is suggestive of numerous connotations: from the artistic free agent with a mix of technical recording skills and aesthetic wherewithal, to the "money" person who stamps their name on recordings due to their capital investment and ownership of studio gear, to the above mentioned multi-tasking artists, to name just three. John Ryan and Michael Hughes posit that, in the popular music industry, the prominence and influence of producers has increased since the 1950s, when record companies began outsourcing their production operations to studios outside the traditional structure of the recording industry (2006: 245-6). Major record labels made the move towards outsourcing production in an effort to stay competitive with the burgeoning independent labels of the 1950s, many of which were focused on marginalized audiences. In this context of displaced production, or "decentralized and open production systems", Ryan and Hughes note that a new role emerged within the industry: "the independent producer" (2006: 245). They write:

[Freed] from the bureaucracy of the major company, armed with the powerful new recording tool of multitrack recording ... the independent producer was now ready to assume a status often equal to, and sometimes exceeding, that of recording artists in the production of popular music (Ryan and Hughes 2006: 245-6).

Sam Philips, who established Sun Records, George Martin, best known for his work with the Beatles, Chet Atkins, who pioneered this role in the realm of commercial country music, and Alfred Lion of the jazz label Blue Note are generally considered the key figures 
of this production model. Their primary roles were to develop a signature sound, develop recording artists and, perhaps most importantly, deliver commercially successful records (Ryan and Hughes 2006: 246). And, as these four examples make clear, the independent producer emerged as the domain of men, echoing Mayhew's sentiments. ${ }^{15}$

As noted above, Phillips, Martin, Atkins and Lion, along with numerous other record producers, engineers and musicians, worked within a context of analog multitrack recording. This type of recording usually relies on a division of labour that is both highly specialized and hierarchical, wherein recording artists work with song writers, producers and engineers who handle the technical side of recording (e.g. setting up microphones and handling the recording equipment). According to Louise Meintjes (2003), who examines various studio settings in post-apartheid South Africa, decision-making along this chain is very hierarchical, with paid session musicians who often have the least amount of technical recording skills and experience resting at the bottom of the stratified division of labour, and with producers generally at the top. Furthermore, Meintjes argues that female vocalists who enter the studio "are tangled in a triple disadvantage: their gendered status maps onto their spatial status", as they usually record vocal tracks from cut off and isolated recording booths, "and onto studio labor differences, where they are artists, not producers" (2003: 102).

What is important here is the way Meintjes' elaborations are suggestive of diverging social relations, ones that do not work well with the production processes pursued by electroclash producers like Peaches and Le Tigre, who produce their work outside of this specialized editing chain. Additionally, the multitrack recording spaces described above are primarily inhabited and dominated by men. Like many of the rap studios that Tricia Rose documents in Black Noise, "where technological discourse merges with a culture of male bonding" (1994: 58), music studios controlled by men often work to prevent access and problematize female participation, particularly as engineers and producers. As Meintjes puts it, "[The] studio is remote and exclusive. It is closed to outsiders" (2003: 87). In this highly gendered situation, men very often act as gatekeepers and decide who can record, the type of material to be recorded and the specific roles that participants are to play. This partially explains why women have primarily only been able to access studio spaces within the popular music industry as singers and, even more rarely, as instrumentalists since the 1940s (Mayhew 2004: 150).

With the increased power, speed and availability of home computers, workstations and digital sound reproduction gear and ever dropping prices for this equipment, women like Peaches have been able to bypass the standard institutional structures of access within the commercial recording industry by setting up their own studios, or places to record. Jonathan Sterne suggested that, in 2006, a decent digital home studio could be put together for around \$2000USD, including cables and microphones, and a workstation, either a computer or a "standalone all-in-one 'digital audio workstation"” (2006: 258). This type of studio would cost even less today, particularly with the growing second hand market for electronics where discarded devices can be purchased for far less than their initial market price. To create an electroclash or electronic dance music "studio", one only needs a 
laptop/computer, a few other outboard recording devices and a room-although one could technically record outdoors. This environment is markedly different from the enclosed and vacuum sealed spaceship-like studio spaces (Meintjes 2003: 88), large mixing consoles, tape machines, and effects units that shaped many other forms of popular music.

The dropping prices of digital recording technologies not only increases access for women, it provides the context for an initial expansion of aesthetics and practices within electroclash, particularly the lo-fi and distorted beats of Peaches' track, "Fuck the Pain Away". Again, to quote Bottner, Peaches' music is recorded "very roughly, noisy, focused on voice and beat" (2005: 99). These grittier timbres and beats challenge established conventions of electronic music production, which is regularly marked by the pursuit of the latest studio technologies and slick/clean sounding productions (see Rodgers 2003). It might be useful to think of the studio practices and music of Peaches as "semiotic expansionism", to borrow from Straw's adaptation of Peter Wollen's semiotic reductionism in Readings and Writings: Semiotic Counter-Strategies (1982). ${ }^{16}$ Peaches was able to write and record most of The Teaches of Peaches using a Roland MC-505 (Bottner 2005: 102), a small portable device also known as a groove-box that functions as a programmable sixty-four note polyphonic synthesizer and drum machine with twenty-six interchangeable drum kits to use in various combinations. With the MC-505, a producer is able to work with a set of previously recorded sonic materials - in other words, sounds that they did not record themselves such as drum timbres, handclaps or bass sounds, etc. - in combination with vocals or any other instruments that can be accessed. In this way, many electroclash studios operate as remix studios where sounds are rearticulated around certain established aesthetic conventions. These conventions are then solidified and circulated by various modes of distribution, whether at club nights, parties or through peer-to-peer file sharing and streaming.

Rather than thinking of these artists as using the latest in hi-tech studio equipment, it is important to emphasize that electroclash artists like Peaches and Le Tigre produced much of their electroclash material by making do with whatever instruments they had access to. The aforementioned MC-505 used to make The Teaches of Peaches was first released in 1998 and was produced by Roland until 2002 as the successor to its MC-303. Although the MC-505 has an accessible user interface for programming rhythm patterns using a step sequencer, it lacks a sampler, is prone to "lock" or "freeze" during real-time operations, and its LCD screen, which displays the device's settings, is very small and tends to lose pixels over time. These supposed design flaws prevented it from being widely accepted amongst electronic dance music producers. Since the MC-505 was not taken up in the same way as Roland's TR-808 drum machine, which is intimately linked with hip hop production and house music, or its TB-303, known as the "acid machine" for its associations with late 1980 s techno and acid house, the MC-505 quickly dropped in value. ${ }^{17}$ While the device initially came with a price tag exceeding $\$ 1200$ USD, it is now readily available on sites like Ebay and Craigslist at prices below $\$ 300$, depending on the condition. Interestingly, as a consequence of such a high degree of innovation, turnover, and competition, with devices and formats constantly being "improved" upon, electronic sound recording equipment can 
lose monetary value rather quickly, thereby making these devices available to those who could not afford them at the time of their release.

Perhaps it is useful to imagine theses producers putting together sounds and making tracks using left over and discarded sound reproduction technologies (see Sterne 2003). As Kathleen Hanna of Le Tigre mentions in conversation with Rodgers: "[We're] really into whatever we can get our hands on at the time, utilizing it to create the sounds we want to make", noting that the group eventually learned ProTools, "so we don't have to rely on an engineer to help us sequence stuff or reorganize stuff at the last minute" (2010: 246). Additionally, the portability of their studio instruments allows the group to work in numerous different spaces, in various combinations-in other words, individually or as a group-and at their own pace, as traditional multitrack studio recording is usually structured by expensive hourly rates. As Hanna puts it:

[The] amazing part about collaboration, especially electronic collaboration, is that we're a group, but we each really get to thrive individually.... There's something about being in your house or the studio by yourself, learning these things on your own time, coming to your own conclusions, and being able to feel like no one's watching you and you can make crazy mistakes and erase it (Rodgers 2010: 253).

Le Tigre's Johanna Fateman adds: "I feel like my best 'art brain' sometimes is happening at 3:00 AM when I'm alone, eating candy in the middle of the night and working on music" (Rodgers 2010: 253).

\section{CONCLUSION}

THE TRANSFORMATIONS to electronic dance music production discussed in this text must also be understood within the broader context of the popular music industry in the 1990s. The artist/entrepreneur electroclash producer crystallized as peer-to-peer file sharing practices proliferated and more traditional, high-end record labels and studios closed their doors, a trend that persists with Cello Studios (Los Angeles, CA) and the Hit Factory (New York City) folding in 2005 (Sterne 2006: 258). Yet even though many of the displaced and hybrid production practices detailed in this article might seem natural now, in the late 1990s and early 2000s there was an expansion of aesthetics and heterogeneity of production practices opened up by the possibilities of digital music culture and the many women who participated as producers and performers. With the increased affordability and availability of (discarded) sound reproduction technologies, artists such as Peaches and Le Tigre were able to move away from costly multitrack recording and into their own spaces, on their own rhythms. These sorts of performative and collaborative production practices subvert many of the ideological underpinnings of electronic music and "challenge the myth of the genderless composer", as McCartney writes (2006: 45). Through the early 2000s, a distinct articulation formed around electroclash, with multitasking producers and DJs attempting to appropriate the chain of creative music production using the backbeat as a shared rhythmic convention. 
It might be tempting to think that the backbeat signified the rhythmic response to the aforementioned initial circulation of vibes and emotions from electronic dance music parties and club nights in the late 1990s and early 2000s. The beat's inherent push-pull feel between 120-35 BPM combined with the folk/rock song structure and the participatory handclaps which mark so many early electroclash tracks have helped to engender a mixed musical audience, as the backbeat invited (indie) rock, new wave and pop music consumers to EDM dance floors. In this way, electroclash operates within electronic dance music's cyclical encounter with various genres of rock music, dating back to at least disco, followed by the early 1980s electro of Afrika Bambaata (Rietveld 2012) and currently associated with the American producer Skrillex (né Sonny John Moore), who released his debut EP, My Name is Skrillex, in 2010. The British/Sri Lankan artist M.I.A. (née Mathangi Arulpragasam), whose music is similarly focused on voice and beat, also continues to make connections with the sounds of electroclash. ${ }^{18}$ Interestingly, M.I.A. began producing music after being introduced to Roland's MC-505 by Peaches while the latter was touring with the British group Elastica in 2001 (Harrington 2005).

In the four years between Peaches' "Fuck the Pain Away" and Alter Ego's "Rocker", electroclash transformed from a vocally driven genre to a largely instrumental genre. Although Peaches remains a prominent and active producer/performer, many other electroclash artists were unable to maintain their careers as electronic dance music producers during this transformative moment. Georgina Born reminds us, drawing on genre theory, "each art or musical work constructs connections to both prior and future or prospective works" (2005: 23), and, in many ways, "Rocker" was electroclash's defining swan song, incorporating certain foundational elements of the genre while signaling new sounds to come. It marks a subtle yet significant stylistic shift from the early electroclash songs produced by Miss Kittin and the Hacker, Peaches, and the many groups and DJs that initially shaped the genre. With "Rocker", the heavy backbeat and synthesizer timbres of electroclash remain along with the classic rock-song structure of verse followed by chorus; however, the track is noticeably more rigid, techno heavy and slightly faster-in other words, it was produced with a faster BPM. "Rocker" also lacks the handclap adornments that coloured many initial electroclash tracks and is marked by the absence of vocals, which have been replaced by screeching hi-frequency synthesizer lines that play out in the song's chorus. The stylizations of "Rocker" are indicative of a larger trend whereby the mid-2000s electroclash had been shortened to electro, as the clash, or "trash", had been expelled. Electroclash's celebrated sexuality and trashiness was pushed to the margins and replaced by a pronounced techno austerity, returning to where it came from.

\section{ACKNOWLEDGMENTS}

I would like to extend many thanks to the following people for their helpful comments and editing suggestions: Andra McCartney, Brian Fauteux, Will Straw, Jonathan Sterne, Cornelius Borck, Hillegonda Rietveld, Bernardo Attias, and Anna Gavanas. I would also like to thank the editors at Dancecult. 


\section{NOTES}

${ }^{1}$ The term "electronic dance music" is employed in this text as an "umbrella term", to borrow from Kembrew McLeod, that denotes "a heterogeneous group of music made with computers and electronic instruments-often for the purpose of dancing" (2001: 60). McLeod employs a "slash" - as in, electronic and/or dance music - to acknowledge that not all musics under this umbrella are "necessarily designed for dancing" (2001: 60). While I will refrain from using this "and/or" marking, I am using the term electronic dance music in a similar way. It is also worth mentioning that electronic dance musics are not just consumed on the dance floor and listeners engage with these musics in many and varied contexts. Interestingly, McLeod's analysis focuses on electronic dance music between 1998 and 1999 and precedes the naming of electroclash. However, the list of more than three hundred genre names compiled by McLeod include various permutations of electro, including "electro", "electro-acoustic", "electro-breaks", and "electro-dub" (McLeod 2001: 60).

${ }^{2}$ A discussion of the various uses of the term "producer" will appear at a later point in this article.

3 The TR - "transistor rhythm" - 808 was produced by the Roland Corporation between 1980-83, and was succeed by the TR-909 from 1983-84. Roughly 12,000 of the former and 10,000 of the latter were assembled (Butler 2006: 64). Many of these devices are still in circulation today and, because of their strong associations with numerous forms of electronic music and artists including hip hop, techno, electro and house, they have become increasingly more expensive as they are highly valued "vintage" musical instruments.

${ }^{4}$ Kay Dickinson writes that initial interest in the vocoder from the pop music world "came from (mainly male) musicians with heavy investments in types of futurism", and mentions its (slightly) later associations with electro artists (2004: 164).

${ }^{5} \mathrm{McC}$ artney acknowledges that numerous texts do not even attempt to define the term electronic music, choosing instead to present a "historical account that defines by description and inclusion or exclusion" (2000b: 4).

${ }^{6}$ For instance, Joel Chadabe writes: "[Electronic] music includes all music made with electronics, whether specifically with computer, synthesizer, or any other special equipment” (1997: x).

${ }^{7}$ I am drawing here from Ahmed, who argues, "[Emotions] are intentional in the sense that they are 'about' something: they involve a direction or orientation towards an object. The 'aboutness' of emotions means they involve a stance on the world, or a way of apprehending the world" (2004: 7).

${ }^{8}$ Hillegonda Rietveld, email to author, 11 June 2012.

${ }^{9}$ Mikey Muscles, interview with the author (Montreal, QC), 11 December 2009. Mike Tessier (aka Mikey Muscles) was the head promoter for Neon Productions (Montreal), working onand-off between 2001-2009. Neon Productions was founded in 1998 and since its inception has booked many of the top international electro artists, along with promoting and creating its own party nights.

${ }^{10}$ Thomas Sontag, interview with the author (Montreal, QC), 23 September 2011. Sontag (aka Thomas Von Party) is a Montreal based DJ and the younger brother of Tiga Sontag, one of the key contributors of electroclash. He became Label Manager and A\&R for Tiga's Turbo Recordings in 2005 when the label was relaunched. Turbo Recordings represents some of the 
world's most popular electro and techno artists, including Ivan Smagghe and Boys Noize.

${ }^{11}$ Mark J. Butler (2006) attempts to broadly deal with electronic dance music while reserving its "detailed analysis" for techno (25). Butler observes that electronic dance music typically works within a range 120-180 BPM (2006: 8). However, it should be noted that many electronic dance music genres operate outside of this range. For instance, many disco cuts are slower than 120 BPM and genres like drum 'n' bass, jungle, gabber, drill and bass, and breakcore all incorporate BPM exceeding 180. Electroclash tracks tend to sit at the lower end of this spectrum, from 120-135 BPM.

${ }^{12}$ As Tim Lawrence posits in Love Saves the Day (2003), the emergence of disco, which, along with dub, is perhaps the first electronic dance music (Veal 2007), can be traced to the developments of Philadelphia-based drummer Earl Young in the early 1970s. In an attempt to make soul music more danceable, Young started playing the bass drum on all four beats of the measure on cuts like "Zing went the Strings of My Heart" (1972) - the first single by his band the Trammps (2003: 120). This beat would be called "four-on-the-floor", the foundation of disco and later in a slightly sped up and more aggressive manifestation, house music.

${ }^{13}$ To listen to the Amen break, please go to: http://en.wikipedia.org/wiki/Amen break.

${ }^{14}$ Ellen Allien resides in Berlin. In 1999, she founded the music label BPitch Control, currently one of the most prominent electronic music labels in the world. In addition to working as a DJ and label boss, Allien is one of the most prolific producers of electroclash and techno.

${ }^{15}$ Virgil Moorefield (2005) develops a similarly gendered narrative vis-à-vis the increasingly prominent role of the producer in popular music over the last fifty years. Moorefield begins with Phil Spector, "who was to inscribe the term 'producer' firmly and indelibly into the vocabulary of pop record-making” (2005: 9), and moves on to discuss the work of various producers, including Brian Wilson, George Martin, Brian Eno, Bill Laswell, Quincy Jones and Trent Reznor, among others.

${ }^{16}$ Will Straw, email to the author, 7 April 2010.

${ }^{17}$ For a discussion of hip hop and Roland's TR-808, see Rose's Black Noise: Rap Music and Black Culture in Contemporary America (1994), Chapter 3, "Soul Sonic Forces" in particular. On the TB-303 and acid house, see Gilbert and Pearson's "Metal Machine Musics" from Discographies: Dance Music, Culture, and the Politics of Sound (1999).

${ }^{18}$ M.I.A. has released three full-length albums since her initial experiments with Roland's MC505: Arular (2005), Kala (2007) and Maya (2010). For a sampling of M.I.A.'s sound, refer to "Galang", from her debut album, Arular.

\section{REFERENCES}

Ahmed, Sara. 2004. The Cultural Politics of Emotion. New York: Routledge.

Born, Georgina. 2005. “On Musical Mediation: Ontology, Technology and Creativity”. Twentieth-Century Music 2(1): 7-36.

Bottner, Nancy. 2005. "Sonic Cyborgs? Engendering Dissonance and Resistance in Popular Music". Annual Review of Critical Psychology 4: Feminisms and Activisms: 97-106.

Butler, Judith. 1990. Gender Trouble: Feminism and the Subversion of Identity. New York and London: Routledge. 
Butler, Mark J. 2006. Unlocking the Groove: Rhythm, Meter and Musical Design in Electronic Dance Music. Bloomington and Indianapolis: Indiana University Press.

Chadabe, Joel. 1997. Electric Sound: The Past and Promise of Electronic Music. Upper Saddle River, NJ: Prentice Hall.

Dickinson, Kay. 2004. “'Believe’: Vocoders, Digital Female Identity and Camp”. In Music, Space and Place: Popular Music and Cultural Identity, ed. Andy Bennett, Stan Hawkins and Sheila Whiteley, 163-79. Burlington, VT: Ashgate.

Gilbert, Jeremy and Ewan Pearson. 1999. Discographies: Dance Music, Culture, and the Politics of Sound. New York and London: Routledge.

Girard, Stéphane. 2011. "(Un)originality, Hypertextuality and Identity in Tiga's 'Sunglasses at Night”. Popular Music 30(1): 105-25.

Gonick, Marnina. 2009. “The Teaches of Peaches: Performance, Hybridity and Resistance”. Girlhood Studies 2(2): 139-42.

Hall, Stuart. 1986. “On Postmodernism and Articulation: An Interview with Stuart Hall”. Journal of Communication Inquiry 10: 45-60.

Harrington, Richard. 2005. “M.I.A., No Loss for Words”. Washington Post. 16 September: <http://www.washingtonpost.com/wp-dyn/content/article/2005/09/15/ AR2005091500697_pf.html> (accessed 27 July 2012).

Henriques, Julian. 2010. "The Vibrations of Affect and their Propagation on a Night Out on Kingston's Dancehall Scene”. Body and Society 16(1): 57-89.

Kronengold, Charles. 2008. "Exchange Theories in Disco, New Wave, and Album-Oriented Rock". Criticism 50(1): 113-32.

Lawrence, Tim. 2003. Love Saves the Day: a History of American Dance Music Culture, 19701979. Durham: Duke University Press.

Loza, Susana. 2001. "Sampling (hetero)sexuality: Diva-ness and Discipline in Electronic Dance Music”. Popular Music 20(3): 349-57.

Luvaas, Brent. 2006. "Re-producing Pop: The Aesthetics of Ambivalence in Contemporary Dance Music”. International Journal of Cultural Studies 9(2): 167-87.

Mayhew, Emma. 2004. "Positioning the Producer: Gender Divisions in Creative Labour and Value". In Music, Space and Place: Popular Music and Cultural Identity, ed. Andy Bennett, Stan Hawkins and Sheila Whiteley, 149-62. Burlington, VT: Ashgate.

McCartney, Andra. 2000a. "Cyborg Experiences: Contradictions and Tensions of Technology, Nature, and the Body in Hildegard Westerkamp's 'Breathing Room'”. In Music and Gender, ed. Pirkko Moisala and Beverley Diamond, 317-35. Urbana and Chicago: University of Illinois Press.

- - - 2000b. "Soundscape Composition and the Subversion of Electroacoustic Norms". Canadian Electroacoustic Community. July: <http://cec.sonus.ca/econtact/Histories/ SoundscapeComposition.htm\#1> (accessed 12 November 2011).

- - 2006. "Gender. Genre, and Electroacoustic Soundmaking Practices". Intersections: Canadian Journal of Music 26(6): 20-48.

McLeod, Kembrew. 2001. "Genres, Subgenres, Sub-Subgenres and More: Music and Social Differentiation Within Electronic/Dance Music Communities". Journal of Popular Music 
Studies 13(1): 59-75.

Meintjes, Louise. 2003. Sound of Africa: Making Music Zulu in a South African Studio. Durham and London: Duke University Press.

Moorfield, Virgil. 2005. The Producer as Composer: Shaping the Sounds of Popular Music. Cambridge: The MIT Press.

Mowitt, John. 2002. Percussion: Drumming, Beating, Striking. Durham: Duke University Press.

Oatmon, Jack. 2009. “Test of Time: Intrepid German Techno Twosome Alter Ego Stay Ahead of the Game”. Montreal Mirror. 24 September: <http://www.montrealmirror. com/2009/092409/music3.html> (accessed 17 April 2011).

Reitsamer, Rosa. 2011. "The DIY Careers of Techno and Drum 'n' Bass DJs in Vienna”. Dancecult: Journal of Electronic Dance Music Culture 3(1): 28-43.

Rietveld, Hildegonda. 2012. "Electro". In Continuum Encyclopedia of Popular Music of the World Volume 8 Genres: North America, ed. John Shepherd and David Horn. London: Continuum.

Resident Advisor. "Germany's Groove Magazine Readers' Poll Awards". <http://www. residentadvisor.net/feature.aspx?541> (accessed 21 October 2011).

Roberts, David. 2006. British Hit Singles \& Albums. 19 $9^{\text {th }}$ ed. London: Guinness World Records Limited.

Rodgers, Tara. 2003. "On the Process and Aesthetics of Sampling in Electronic Music Production”. Organised Sound 8(3): 313-20.

- - - 2010. Pink Noises. Durham: Duke University Press.

Rose, Tricia. 1994. Black Noise: Rap Music and Black Culture in Contemporary America. Hanover: University Press of New England.

Ryan, John and Michael Hughes. 2006. "Breaking the Decision Chain: The Fate of Creativity in the Age of Self-Production”. In Cybersounds: Essays on Virtual Music Culture, ed. Michael D. Ayers, 239-54. NewYork: Peter Lang.

Sterne, Jonathan. 2003. The Audible Past: Cultural Origins of Sound Reproduction. Durham: Duke University Press.

_- - 2006. “On the Future of Music”. In Cybersounds: Essays on Virtual Music Culture, ed. Michael D. Ayers, 255-64. New York: Peter Lang.

Straw, Will. 2001. "Systems of Articulation, Logics of Change: Scenes and Communities in Popular Music". Cultural Studies 5(3): 368-88.

Sullivan, Caroline. 2006. "Filth and Fury". The Guardian. 24 July: < http://www.guardian.co.uk/ music/2006/jul/24/electronicmusic.urban> (accessed 23 November 2011).

Veal, Michael E. 2007. Dub: Soundscapes and Shattered Songs in Jamaican Reggae. Middletown, CT: Wesleyan University Press.

Wallace, David Foster. 1997. "E Unibus Pluram: Television and U.S. Fiction”. In A Supposedly Fun Think I'll Never Do Again: Essays and Arguments, 21-82. New York: Back Bay Books.

Wollen, Peter. 1982. Readings and Writings: Semiotic Counter-Strategies. Brooklyn and London: Verso Books. 


\section{DISCOGRAPHY}

Afrika Bambaata and The Soul Sonic Force. 1982. "Planet Rock". Planet Rock. Tommy Boy (12-inch): TB-823. < http://www.discogs.com/ Afrika-Bambaataa-the-Soul-Sonic-Force-Music-By-Planet-Patrol-Planet-Rock/release/2047>.

Alter Ego. 2004. "Rocker”. Rocker. Skint Records (12-inch): Skint 103.

<http://www.discogs.com/Alter-Ego-Rocker/release/338153>.

- - 2004. Transphormer. Klang Elektronik (12-inch): Klang Elektronik 85. < http://www. discogs.com/Alter-Ego-Transphormer/release/291892>.

Chicks on Speed. 2003. "We Don't Play Guitars". 99 Cents. Chicks on Speed Records (LP): COSR012. http://www.discogs.com/Chicks-On-Speed-99-/release/377693 >.

Cybotron. 1983. "Clear". Clear. Fantasy (12-inch): D-216.

<http://www.discogs.com/Cybotron-Clear/release/17859>.

G.L.O.B.E. and Wiz Kid. "Play that Beat Mr. DJ". Play that Beat Mr. DJ. Tommy Boy (12inch): TB 836. <http://www.discogs.com/GLOBE-Whiz-Kid-Play-That-Beat-Mr-DJ/ release/43616>.

Joy Division. 1980. "Love Will Tear us Apart". Love Will Tear Us Apart. Factory Records (7-inch): FAC 23. < http://www.discogs.com/Joy-Division-Love-Will-Tear-Us-Apart/ release $/ 28027>$.

Kraftwerk. 1977. “Trans-Europe Express”. Trans-Europe Express. Kling Klang (LP): 1C 064-82 306. <http://www.discogs.com/Kraftwerk-Trans-Europa-Express/release/75547>.

Le Tigre. 2001. Feminist Sweepstakes. Mr. Lady (CD Album): MRLR-19.

<http://www.discogs.com/Le-Tigre-Feminist-Sweepstakes/release/111532>.

———. 1999. "Hot Topic". Le Tigre. Mr. Lady (CD Album): MRLR-07.

$<$ http://www.discogs.com/Le-Tigre-Le-Tigre/release/221309>

MFSB. 1973. "Love is the Message". Love is the Message. Philadelphia International Records (LP): PIR 65864. < http://www.discogs.com/MFSB-Love-Is-The-Message/release/173702>.

M.I.A. 2005. “Galang”. Arular. XL Recordings (CD Album): XLCD 186. < http://www.discogs. com/MIA-Arular/release/422508>.

- - . 2007. Kala. XL Recordings (CD Album): XLCD281. < http://www.discogs.com/ MIA-Kala/release/1041774 >.

———. 2010. Maya. XL Recordings (CD Album): B0014344-02. < http://www.discogs.com/ MIA---Y-/release/2353769>.

Miss Kittin and the Hacker. "Frank Sinatra". First Album. International Deejay Gigolo Records (CD Album): Gigolo 75. < http://www.discogs.com/Miss-Kittin-The-Hacker-First-Album/ release $/ 20345>$.

New Order. 1983. Blue Monday. Factory Records (12-inch): FAC 73.

<http://www.discogs.com/New-Order-Blue-Monday/release/20755>

Peaches. 2000. "Fuck the Pain Away". The Teaches of Peaches. Kitty-Yo (CD Album):

KY00033CD. <http://www.discogs.com/Peaches-The-Teaches-Of-Peaches/release/50236>.

——. 2003. "Shake Yer Dix". Fatherfucker. XL Recordings (CD Album): XLCD 171. 
<http://www.discogs.com/Peaches-Fatherfucker/release/189103 $>$.

-_- 2006. Impeach My Bush. XL Recordings (CD Album): XLCD201.

<http://www.discogs.com/Peaches-Impeach-My-Bush/release/728316>.

- - - 2009. I Feel Cream. XL Recordings (CD Album): XLCD415.

< http://www.discogs.com/Peaches-I-Feel-Cream/release/1735591>.

Skrillex. 2010. My Name is Skrillex. Self-released (EP): MP3. < http://www.discogs.com/ Skrillex-My-Name-Is-Skrillex-EP/release/2446784>.

The Cult. 1985. "She Sells Sanctuary". Love. Beggars Banquet (CD Album): BEGA 65CD. <http://www.discogs.com/Cult-Love/release/440460>.

The Winstons. 1969. "Amen, Brother". Color Him Father/Amen, Brother. Metromedia Records (7-inch): MMS-117. <http://www.discogs.com/Winstons-Color-Him-Father-Amen-Brother/ release/423956>.

Tiga and Zyntherius. 2001. "Sunglasses at Night”. Sunglasses EP. International Deejay Gigolo Records (12-inch): Gigolo 80. < http://www.discogs.com/Tiga-Zyntherius-Sunglasses-EP/ release $/ 18500>$.

Trammps. 1972. "Zing Went the Strings of My Heart”. Zing Went the Strings to My Heart. Buddah Records (7-inch): 2011-140. < http://www.discogs.com/ Trammps-Zing-Went-The-Strings-Of-My-Heart/release/2589489>.

Ultimate Breaks \& Beats. 1986. Street Beat Records (LP COMP): SBR 501. <http://www. discogs.com/Various-Ultimate-Breaks-Beats/release/176831>.

\section{FILMOGRAPHY}

“Afrika Bambaata \& Soul Sonic Force-Planet Rock". 2009. YouTube, 4:00.

<http://www.youtube.com/watch?v=91DCYjb8RHk> (accessed 13 June 2012).

"Cybotron-Clear". 2008. YouTube, 4:47.

<http://www.youtube.com/watch?v=fGqiBFqWCTU > (accessed 20 December 2011).

"Fuck the Pain Away-Peaches". 2009. YouTube, TIME.

$<$ http://www.youtube.com/watch? $=$ KHcMqOQt4NY\&feature=related $>($ accessed 5

December 2011).

“Kraftwerk-Trans Europe Express (Long Version)". 2011. YouTube, 14:01.

<http://www.youtube.com/watch?v=PMGuxjspgrQ> (accessed 7 December 2011).

M.I.A. 2005. "M.I.A.—Galang”. YouTube, 3:32. <http://www.youtube.com/ watch?v=DCL1RpgYxRM $>$ (accessed 27 July 2012).

"Miss Kittin Frank Sinatra". 2010. YouTube, 3:40.

$<$ http://www.youtube.com/watch?v=PjA8NMIXdA8\&feature $=$ fvw $>$ (accessed 17 October 2011).

Schamoni, Deborah. 2003. "Chicks on Speed-We Don't Play Guitars". YouTube, 3:58. < http:// www.youtube.com/watch?v=gZMwkDTONpM > (accessed 12 June 2012).

Stubi, Corine. 2004. "Alter Ego-Rocker (Official video)". YouTube, 2:28.

$<$ http://www.youtube.com/watch?v=uiwFATVWVgA > (accessed 20 October 2012). 
"The Trammps-Zing Went the Strings of My Hear". 2008. YouTube, 3:17. < $\underline{\text { http://www. }}$ youtube.com/watch?v=vx0pnqoenbQ> (accessed 6 November 2011).

“The Winstons-Amen Brother”. 2009. YouTube, 2:33.

$<$ http://www.youtube.com/watch?v=GxZuq57 bYM> (accessed 15 June 2012).

“Tiga \& Zyntherius-Sunglasses At Night (2001)”. 2010. YouTube, 3:42. < http://www.youtube. com/watch?v=rQk4BaUg7YE $>$ (accessed 15 June 2012). 